\title{
Recent expansion of the alien invasive blue crab Callinectes sapidus (Rathbun, 1896) (Decapoda, Crustacea) along the Bulgarian coast of the Black Sea
}

\author{
Tihomir Stefanov
}

National Museum of Natural History, Bulgarian Academy of Sciences, 1 Tsar Osvoboditel Blvd, 1000 Sofia, Bulgaria, tishos@gmail.com; https://orcid.org/0000-0003-1084-8358

\begin{abstract}
Thirteen new records of the blue crab Callinectes sapidus (Rathbun, 1896) have been documented near the Bulgarian Black Sea coast since 2006. This is an evidence for a recent expansion of the species in this part of the Black Sea. This expansion could be explained by the existing of established population in the area and is confirmed by the capturing of an egg-bearing female in the Varna Bay in 2005.
\end{abstract}

Keywords: allochthonous species, Bulgarian Black Sea coast, Callinectes sapidus

The native area of the blue crab Callinectes sapidus (Rathbun, 1896) covers the west coast of the Atlantic Ocean from Nova Scotia, Canada to northern Argentina to the south, including some islands in the area like the Bermudas and the Antilles, as well as estuaries and lower reaches of the rivers, flowing directly into the ocean (Shaverdashvili \& Ninua, 1975; Meise \& Stehlik, 2003; Nehring et al., 2008).

In the last century, the distribution of this species became wider and reached the eastern part of the Atlantic Ocean including the Mediterranean Sea Basin (Pashkov et al., 2012). The first record from European waters is dated back to 1900 when the species was found on the Atlantic coast of France in the estuary of the Gironde River (Shaverdashvili \& Ninua, 1975; Nehring et al., 2008). Later it was found also in the Netherlands in 1932, Denmark in 1951, on the North Sea coast of Germany in 1964 and near the coasts of UK in 1975 (Clark, 1984; Nehring, 2011). In Portugal it was recorded in 1979 and in Belgium the first record was from 1981 (Nehring et al., 2008; Jansen, 2010).
The species has been found also near the Atlantic coast of Spain in 2002 (Cabal et al., 2006).

In the Mediterranean Sea, it was first recorded in Greece in 1948 and soon after that near Italy in 1949 (Gennaio et al., 2006). Later, it was established near the Mediterranean coast of Israel in 1951 and of Turkey in 1959 (Holthuis, 1961).

The first blue crab found in the Black Sea has been caught in a fishing net during the night of 2 October, 1967 in the western part of the Varna Bay (Bulgurkov, 1968). Few years later, in 1971, the species was found in the eastern part of Black Sea near the coast of Georgia (Shaverdashvili \& Ninua, 1975), as well as in the northern part of the sea near the Ukrainian (1975) and Russian (1979) coasts (Pashkov et al., 2012). In 1998, it was found for the first time in Romanian waters (Pashkov et al., 2012). Recently, the blue crab has been recorded in the Sea of Azov in 2006 (Diripasko et al., 2009) and near the Crimean Peninsula in 2007. The first discovery of the species near the Turkish Black Sea coast is from 2014, near Duzce and Zonguldak 


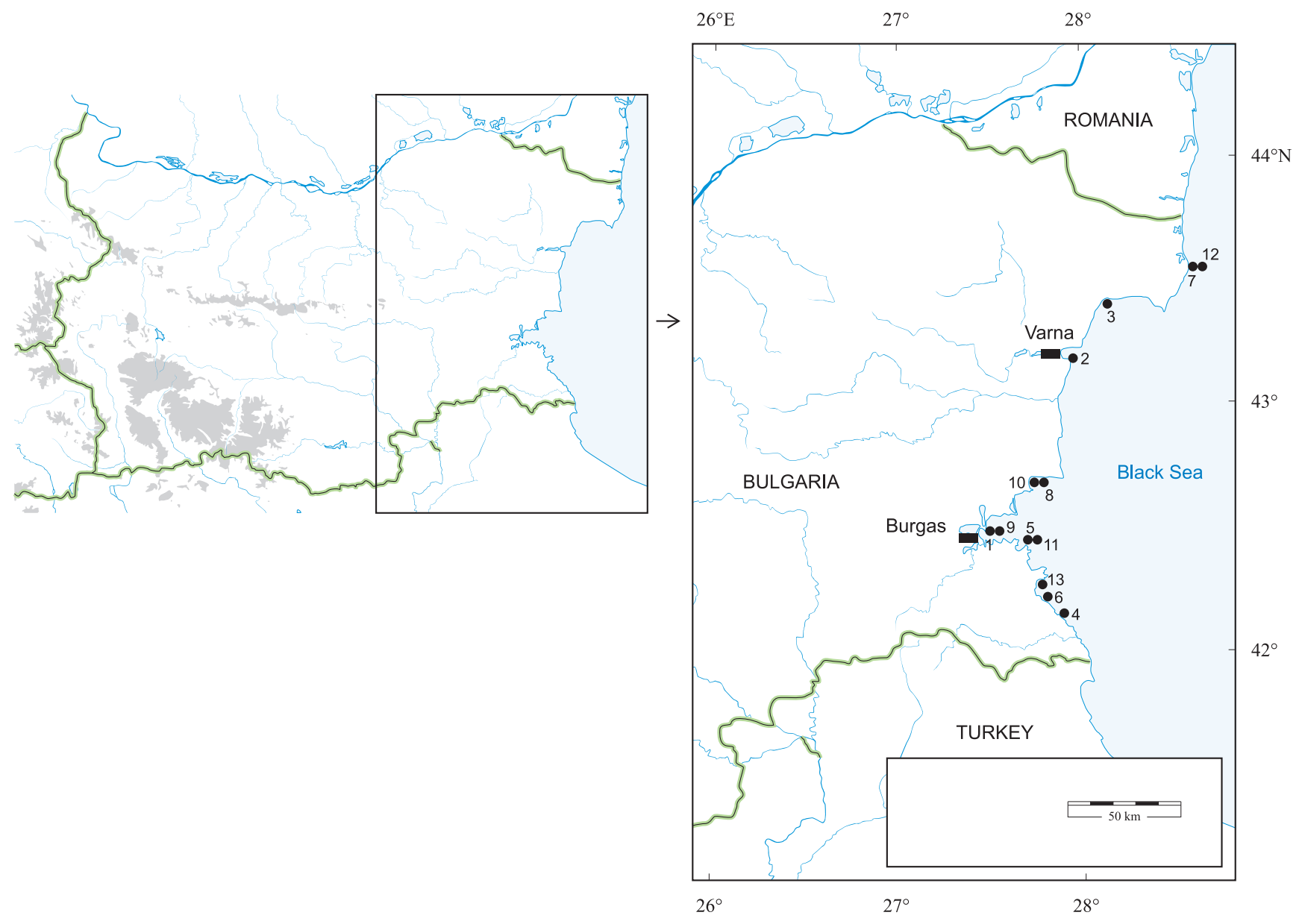

Fig. 1. Map of the localities, where Callinectes sapidus was found along the Bulgarian Black Sea coast since 2006. The numbers on the map correspond to the documented records of the species described in the text.

(Yağhoğlu et al., 2014), but soon after that a south-eastward expansion has been recorded, as a female specimen has been found near Trabzon in the southern easternmost part of the Black Sea (Ak et al., 2015).

According to Ak et al. (2015), there are a total of 14 records of $C$. sapidus in different parts of the Black Sea. In his overview paper Hubenov (2015) reported a total of four localities of the species for the Bulgarian sector of the Black Sea (cape Kaliakra, Balchik, Varna and Burgas), but without giving any additional information about dates, number of caught specimens and precise locations. According to Uzunova (2016), in 2005 six blue crabs were caught by fishermen in the Varna Bay, one of which was an egg-bearing female. Apart of all published information, in the last years there are 13 more documented records of the blue crab near the Bulgarian Black Sea coast (Fig. 1). They are as follows:
1 2006. A male blue crab was caught in Burgas Bay in a fishing net by a local fisherman on 22 August. The specimen is deposited in the scientific collections of the Regional History Museum in Burgas.

2 2007. A male crab was collected by a scuba diver in January near Galata Cape (Varna district).

3 2007. One specimen, caught near the town of Balchik was delivered to the aquarium of the Institute of Fisheries Resources, Varna.

4 2008. One specimen was caught in a gill net by a local fisherman in the village of Ahtopol.

5 2009. One blue crab was caught in June in a fish trap near St. Petar Island in the vicinity of the town of Sozopol.

6 2009. Another specimen was caught in a gill net by a local fisherman near the town of Tsarevo.

7 2010. One specimen was caught in November in a gill net by a local fisherman near Shabla Cape. 
8 2012. There is unconfirmed information about the capture of one specimen near the Sveti Vlas Village.

9 2013. One blue crab was caught in October and delivered to the Regional History Museum in Burgas.

10 2015. One adult specimen was observed in July on the sand beach of Sunny Beach Resort; there is a video record confirming the observation.

11 2016. One male specimen was caught in October in a gill net by local fishermen near the town of Sozopol.

12 2016. One female specimen was caught in the middle of November in a gill net by a local fisherman near Shabla Cape. The specimen was delivered in the National Museum of Natural History, Sofia (NMNHS) and deposited in the hydrobiological collections of the museum.

13 2017. One male specimen was caught in the Vasiliko District near Kiten Village.

The question how the blue crab penetrates into the Black Sea and the Sea of Azov is still open. The common opinion is that it was introduced with ballast waters of commercial ships helped by the long duration of the larval stages of the species (Zaitsev \& Ozturk, 2001; Diripasko et al., 2009; Jensen, 2010). The main evidence is the fact that the blue crabs were often found near big ports, where ballast waters most frequently were discharged (e.g., Varna, Konstanta, Sevastopol, Novorossiysk, Trabzon). However, the recent records of the species along the Bulgarian coast show that the blue crab is spread not only around big ports. Indeed on the contrary, only three of the 13 new founds are near the two biggest Bulgarian ports Varna and Burgas. We assume that the frequency of introductions of this species nowadays is low and it is quite unlikely to detect it directly after its introduction. It is well known that $C$. sapidus is a very good swimmer and capable of distant migrations. For example, few tagged female specimens have been recovered 100 to $540 \mathrm{~km}$ from their initial places of release (Hill et al., 1989). Therefore, we think that last years the spreading of the species in the Black Sea is due to natural dispersal rather than ballast water introduction.

In our opinion, there are two stages with different ways of penetration of the blue crab into the Black Sea and the Sea of Azov. In the first stage (approximately till the end of the 20th century), the species was initially introduced in the area with ballast waters and for that reason it was found mainly near big ports - a total of six founds near Varna, Poti, Kerch, Novorossyisk and Constanta (see the map in Pashkov et al., 2012). In the second stage, most of the blue crab founds in the area are due to natural dispersal from the Mediterranean Sea trough the Bosphorus. At that time in the Eastern Mediterranean near the Turkish coasts, a wellestablished population of this species is known to exist, with 15 known localities in different lagoons some with large well-developed populations (Enzenrob et al., 1997). Yağhoğlu et al. (2014) reported the species for the first time near the Turkish coastal waters of the Black Sea, indicating an eastward migration of the blue crab. However, its further south-eastward expansion near the Trabzon Harbour is most probably due to ballast water transfer, as it has been found close to the harbour and the shipping routes (Ak et al., 2015). In the second stage, $C$. sapidus reached also the Sea of Azov (Diripasko et al., 2009) and according to Pashkov et al. (2012), practically all cases of blue crab findings in the Azov-Black Sea basin in this period could be explained by their migration from the Bosphorus along the gradient of the salinity decrease of the surface waters. The migration of the blue crabs to the eastern part of the Black Sea and the Sea of Azov has been assited also by the Anatolian and Caucasian currents.

In our opinion, the recent expansion of the blue crab near the Bulgarian Black Sea coast is also due to natural dispersal, as suggested by the fewer (only three) founds near the big ports. The other ten founds have been spread all over the Bulgarian coast and concentrated mainly near the biggest fishermen villages, which means that the crabs are found where the fishing activity is higher, because they are often caught in the fishermen gillnets. According to us, nowadays the blue crab is widely spread along the Bulgarian coast and more finds could be expected, especially around the fishermen settlements.

There is still an open question how the blue crabs spread around the Bulgarian coast, because their direct migration from the Mediterranean would have been hindered by the strong Rumelian current, which is directed from North to South towards the Bosphorus. According to the recent founds of the species in the AzovBlack Sea basin, it is most numerous around the Bulgarian coast (13 out of 21 founds since 2006), which makes the migration from other parts of the sea quite improbable. This opens again the question about the level of naturalisation of C. sapidus in the area. The natural conditions in the Black Sea, including its temperature regime and low salinity should be quite suit- 
able for the blue crab, which is generally an eurybiontic species. It inhabits sites with wide range of chemical and physical environmental conditions and is omnivorous (Hill et al., 1989). The blue crab possesses specific reproductive biology as the mating takes place in relatively low salinity areas of estuaries and after that, females migrate to sites with higher salinity to spawn. Female crab mate only once, but can produce few millions of eggs (Jansen, 2010). Suitable natural conditions are available near the Bulgarian coast and the egg-bearing female found in the Varna Bay in 2005 (Uzunova, 2016) is a direct evidence for the existing of an established population of the species and explains the high number of new founds in the area since 2006. Our study reported only founds of large adult individuals but the recent record of mature female specimen near the Shabla Cape (in 2016), which could had spawned shortly before it was caught, should get special attention. This found could be another evidence for the existing of an established population of $C$. sapidus along the Bulgarian Black Sea coast, which is the reason for the recent expansion of the species.

\section{References}

Ak O., Haşimoğlu A., Bayram K. 2015 Southeastward expansion of the blue crab Callinectes sapidus (Rathbun, 1896) in the Black Sea. Cahiers de Biologie Marine 56: 397-399.

Bulgurkov K. 1968 Occurrence of Callinectes sapidus Rathbun (Crustacea - Decapoda) in Black Sea. Proceedings of the Research Institute of Fisheries and Oceanography - Varna 9: 97-99. (In Bulgarian)

Cabal J., Milán J.A.P., Arronte J.C. 2006 A new record of Callinectes sapidus Rathbun, 1896 (Crustacea: Decapoda: Brachyura) from the Cantabrian Sea, Bay of Biskay, Spain. Aquatic Invasions 1 (3): 186-187.

Clark P.F. 1984 Recent records of alien crabs in Britain. Naturalist 109: 111-112.

Diripasko O.A., Izergin L.V., Koshkalda A.I. 2009 The First Finds of Blue Crab, Callinectes sapidus (Portunidae, Decapoda), in Sea of Azov. Vestnik Zoologii 43 (6): 529-532. (In Russian)

Enzenrob R., Enzenrob L., Bingel F. 1997 Occurrence of blue crab Callinectes sapidus (Rathbun, 1896) (Crustacea, Brachyura) on the Turkish Mediterranean and the Adjacent Coast and Its Site Distri- bution in the Bay of Iskenderun. Turkish Journal of Zoology 21: 113-122.

Gennaio R., Scordella G., Pastore M. 2006 Occurence of blue crab Callinectes sapidus (Rathbun, 1896, Crustacea, Brachyura), in the Ugento Ponds area (Lecce, Italy). Thalassia Salentina 29: 29-39.

Hill J., Fowler D.L., Van Den Avyle M.V. 1989 Species profiles: life histories and environmental requirements of coastal fishes and invertebrates (Mid-Atlantic) - Blue crab. U. S. Fish and Wildlife Service Biological Report 82: 1-18.

Holthuis L.B. 1961 Report on a collection of Crustacea, Decapoda and Stomatopoda from Turkey and the Balkans. Zoologische Verhandelingen 47: $1-67$.

Hubenov Z. 2015 Species composition of the free living multicellular invertebrate animals (Metazoa: Invertebrata) from the Bulgarian sector of the Black Sea and the coastal brackish basins. Historia naturalis bulgarica 21: 49-168.

Jansen K.R. 2010 NOBANIS - Invasive Alien Species Fact Sheet - Callinectes sapidus. From: Identification key to marine invasive species in Nordic waters - NOBANIS www.nobanis.org, Date of access 11/01/2017.

Meise C.J., Stehlik L.L. 2003 Habitat Use, Temporal Abundance, Variability and Diet of Blue Crabs from a New Jersey Estuarine System. Estuaries 26 (3): 731-745.

Nehring S. 2011 Invasion History and Success of the American Blue Crab Callinectes sapidus in European and Adjacent Waters. In: Galil B.S., Clark P.F., Carlton J.T. (eds) In the Wrong Place Alien Marine Crustaceans: Distribution, Biology and Impacts. Invading Nature - Springer Series in Invasion Ecology 6: 607-624.

Nehring S., Speckels G., Albersmeyer J. 2008 The American blue crab Callinectes sapidus Rathbun on the German North Sea coast: Status quo and further perspectives. Senckenbergiana maritima 38 (1): 39-44.

Pashkov A.N., Reshetnikov S.I., Bondarev K.B. 2012 The Capture of the Blue Crab (Callinectes sapidus, Decapoda, Crustacea) in the Russian Sector of the Black Sea. Russian Journal of Biological Invasions $3(1): 22-28$.

Shaverdashvili R.S., Ninua N.Sh. 1975 New find of crab Callinectes sapidus Rathbun, 1896 in the Black Sea. Nauch. Dokl. Vyssh. Shkol. 9: 19-20. (In Russian) 
Recent expansion of the alien invasive blue crab Callinectes sapidus along the Bulgarian coast of the Black Sea

Uzunova S. 2016 Field guide of Decapoda (Crustacea) from the Bulgarian sector of the Black Sea. ArtTracer Publ., Varna, 128 pp.

Yağhoğlu D., Turan C., Öğreden T. 2014 First record of blue crab Callinectes sapidus (Rathbun, 1896) (Crustacea, Brachyura, Portunidae) from the Turk- ish Black Sea coast. J. Black Sea/Mediterranean Environment 20 (1): 13-17.

Zaitsev Y., Ozturk B. 2001 Exotic species in the Aegean, Marmara, Black, Azov and Caspian Seas. Turkish Marine Research Foundation, Istanbul, $265 \mathrm{pp}$. 